\title{
The Role of Enterprise Risk Management in Enhancing Firm Value Before and During the Covid- 19 Pandemic in Indonesia
}

\author{
Sidik Ismanu*, Anik Kusmintarti, Edi Winarto \\ Accounting Department \\ State Polytechnic of Malang \\ Malang, Indonesia \\ *sidik.ismanu@polinema.ac.id, anik.kusmintarti@polinema.ac.id, edi_polinemalang@yahoo.co.id
}

\begin{abstract}
The aim of this study is to investigate the level of implementation of corporate risk management has a positive effect on firm value. Firm value is the investor's perception of the company's financial performance. The company's financial performance is often associated with share prices. Maximizing company value is very important for a company. The increase in company value is in accordance with the wishes of investors. Using a dataset of 12 banking financial service companies and 7 construction \& property companies that have gone public in Indonesia. The data collection period is from 2017 to 2020. Tobin's $Q$ is used to measure company value. Tobin's $Q$ as a function of corporate risk management, and fundamental factors consisting of firm size, liquidity, leverage, profitability. Hypothesis testing with multiple linear regression. The findings of this study, in normal conditions there is a relationship between the application of risk management and the company's fundamental factors on firm value. During the Covid-19 pandemic, the company experienced a decline in the company's financial performance, resulting in the application of risk management and company fundamental factors that did not have a significant effect on company value.
\end{abstract}

Keywords-enterprise risk management, firm size, liquidity, leverage, profitability, firm value

\section{INTRODUCTION}

The corona virus outbreak, which has developed into a covid-19 pandemic, has a serious impact on a country's economy. Population mobility has dropped sharply due to the quarantine and lockdown policies of an area, causing weakening purchasing power and a stagnant economy. At the macro level, the covid-19 pandemic caused the worst global recession since the 1930s. Several countries experienced a decline in gross domestic product in the first quarter of 2020 compared to the same period last year. Many companies go bankrupt, as a result of not being able to meet short-term and long-term obligations. The covid-19 pandemic could affect the stock market and company performance. The impact of this large public health emergency needs to be evaluated on the performance of corporations in this difficult economic period, because issuers are a basic component of the national economy. Investigations suggest that internal factors in the financial system may be the main cause of the economic downturn in recent years [1].

The Covid-19 pandemic, which has lasted until the second quarter of 2020, has plunged many companies with negative financial performance. Even so, there are some companies that still show positive financial performance, and outshine. The company's success in surviving this pandemic cannot be separated from the company's efforts to change its strategy by implementing a more serious corporate risk management.

Enterprise risk management is the process of planning, organizing, implementing and supervising business activities with the possible consequence of the risk of loss. Properly implemented corporate risk management will be able to minimize the risks that occur in the company, especially liquidity, credit, financial, operational, legal risks, and even risks due to external factors of the company.

The objectives that the company can achieve in carrying out corporate risk management are to improve management and financial capabilities, the company in facing any market turmoil and external factors, improve the strategy and quality of corporate risk management so that the company has an advantage, is competitive in business or products, pricing and processes the company's operational business. In addition, it is also expected to increase the confidence of investors, business partners and consumers in the company. Improve the capabilities of all levels of the company in solving any problems that occur, especially those related to significant risks [2].

The success of implementing corporate risk management will increase company competitiveness and increase company value. Firm value is the investor's perception of the company's success rate which is often associated with stock prices. A high share price makes the company value high, and increases market confidence. High share prices reflect the company's current performance, but also on the company's prospects in the 
future. Maximizing company value is very important for a company, because maximizing company value means maximizing the company's main objective. The increase in the value of the company is an achievement in accordance with the wishes of the owners, because with the increase in the value of the company, the welfare and prosperity of the owners will also increase.

The size of the company value is determined by the stock price in the market. A fluctuating share price as a measure of the company's value. The value of a company can be judged by its stable stock price and has increased in the long run because an increase in stock price is identical to an increase in the wealth of investors. Firm value is valued as the number of shares multiplied by the market value per share. Companies have debt as an important thing. Efficient debt management (leverage) has a significant impact on increasing company revenues. Companies that grow with increasing profits, make the demand for shares in the market to increase, and likewise investor confidence in these shares increases. High corporate value is the desire of all company owners. High company value illustrates that the level of prosperity of shareholders is also high. Company value as the basis for seeing the company's prospects.

Company Value is the selling value of a company as an operating business. The existence of an excess selling value over the liquidation value is the value of the management organization that runs the company [3]. Firm value is influenced by many factors, including financial performance and implementation of corporate risk management. Financial performance measures the level of success of management in managing financial resources owned by the company. The higher the financial performance, the higher the company value. Profitability can significantly affect firm value because the higher the profitability the higher the guaranteed profit sharing for investors.

Enterprise risk management is associated with increasing uncertainty. Uncertainty is caused by local and global economic conditions. At this time the uncertainty was caused by the covid-19 pandemic that was sweeping the world. The Covid-19 pandemic that has hit Indonesia since February 2020 , and this pandemic has an impact on business activities, and especially on the Indonesian stock exchange market. The Covid-19 pandemic still cannot predict when it will end. These conditions, which impacted the stock price index in the first quarter to the second quarter of 2020, experienced a significant decline. The development of the stock price index from August 2019 to August 2020 [4], is shown in the figure 1 below.

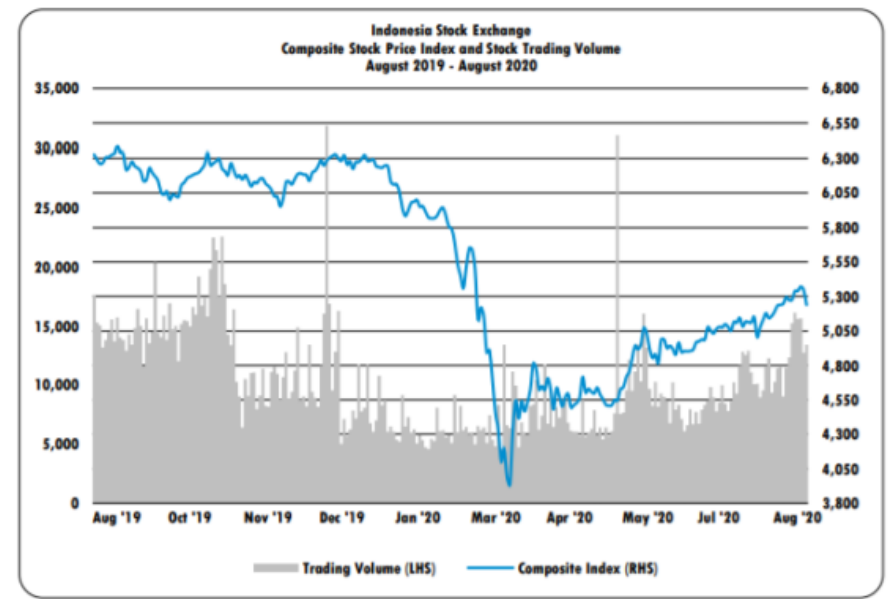

Fig. 1. Indonesia stock exchange composite stock price index and stock trading volume August 2019 - August 2020.

Investors not only need high returns, but also guarantee the security of funds provided. The need to implement corporate risk management, in general, is the influence of internal company. According to agency theory, the company's risk management mechanism is to provide security for risks that may arise in the future after funds are deposited by investors. Company risk management is equipped with guidelines for carrying out future company operations, so that the optimization of company risk management can affect the company's financial performance.

Improved company performance that is supported by good corporate risk management can generate more optimal revenue. This will make the company value better. Research on the effect of corporate risk management on firm value in go public companies in Indonesia. It is stated that there is a relationship between company risk management and firm value, but there is no positive and significant effect of corporate risk management on firm value [5]. Research to determine the effect of corporate risk management on firm value [6]. The process of testing the hypothesis, company risk management followed by financial ratios, states that there are several financial ratios that affect firm value, and do not support the hypothesis that companies that carry out corporate risk management have implications for firm value. There is a positive effect of company risk management on firm value [7].

This study analyzes the relationship between risk management and company fundamental factors on firm value. Enterprise risk management as a dummy variable. In this analysis to determine the difference between companies that implement and do not implement corporate risk management. The company fundamental factors that are relevant in this study are company size, leverage, liquidity, and profitability.

\section{METHODS}

This type of research is survey research, which is research conducted with data collection techniques using questionnaires, interviews and documentation. The research approach used in 
this research is a quantitative approach in analyzing data, taking into account the data obtained and the results of quantitative or quantitative research surveys in the form of numerical or qualitative forms, and many empirical studies have been conducted before, so that the literature review is adequate, the variables already known, and supporting theories already exist. The data obtained were analyzed using statistics to answer questions and test the research hypothesis. The results of the statistical test are used to explain the position of the studied variables and predict the relationship between one variable and another [8].

This research was conducted at Bank Service Companies and Construction \& Building Sector Service Companies that go public in Indonesia. The sampling technique was purposive sampling, and obtained 12 Bank Service Companies, and 7 Construction \& Building Service Companies. Using the company's quarterly financial dataset from 2017 to 2020 . The type of data used in this study is quantitative data, namely nominal and ratio data types. The data source is secondary data in the form of financial reports obtained from the Indonesia Stock Exchange. The method of collecting data is by recording the required data which is listed in the company's quarterly financial statements. The data is processed and presented in the form of tabulations and graphs that are informative. The dependent variable in this study is firm value. The independent variables are enterprise risk management, firm size, debt ratio, current ratio, return on assets. The analysis technique to test and prove the hypothesis uses multiple linear regression analysis with a significance level of $5 \%$ used. The multiple linear regression analysis model is formulated as follows:

$$
\mathrm{Y}=\beta_{1} \mathrm{ERM}+\beta_{2} \mathrm{FS}+\beta_{3} \mathrm{DB}+\beta_{4} \mathrm{CR}+\beta_{5} \mathrm{ROA}
$$

Explanation: $Y=$ Firm Value, ERM=Enterprise Risk Management, FS=Firm Size, DR=Debt Ratio, $C R=$ Current Ratio, ROA=Return On Assets, and $\beta_{1}, \beta_{2}, \beta_{3}, \beta_{4}$, and $\beta_{5}=$ Regression Coefficient.

The operational definition of the variables used in the study:

- Firm value is determined using Tobin's Q which is measured or calculated by dividing the market value of an issuer by the replacement value of the company's assets. Tobin's Q formula and calculation:

Tobin's $Q=\frac{\text { Equity Market Value }}{\text { Equity Book Value }}$

Equity market value is calculated from the number of shares outstanding multiplied by the closing share price.

- Enterprise risk management is a process, which is influenced by the board of directors, management, and other personnel in the company, which is applied at a strategic and comprehensive level, which is designed to identify potential events that can affect the company and to provide reasonable assurance of achieving goals. company [9]. Enterprise risk management as a dummy variable. If the company implements enterprise risk management enterprise risk management is worth 1 , and vice versa is worth 0 .

- Firm size is the average total net sales for the year concerned over several years. In this case the sales are greater than the variable costs and fixed costs, the amount of income before tax will be obtained. Conversely, if sales are smaller than variable costs and fixed costs, the company will suffer losses [3]. The Firm Size formula is:

$$
\text { Firm Size }=\text { Log }(\text { Total Assets })
$$

- Debt ratio is a measure of leverage. Leverage is the company's ability to use fixed cost assets or funds to increase the level of income (return) for company owners [3]. The Debt Ratio formula is:

$$
\text { Debt Ratio }=\frac{\text { Total Debt }}{\text { Total Assets }}
$$

- Current ratio is a measure of liquidity. Liquidity is matters related to the problem of a company's ability to meet its financial obligations that must be paid immediately [3]. The current ratio formula is:

$$
\text { Current Ratio }=\frac{\text { Current Assets }}{\text { Current Liabilities }}
$$

- Return on assets is a measure of profitability. Profitability is the company's ability to earn profits in relation to sales, total assets, and own capital [3]. The Return On Assets formula is:

$$
\text { Return On Assets }=\frac{\text { Earning After Taxes }}{\text { Total Assets }}
$$

\section{RESULTS AND DISCUSSION}

The results of the national survey in Indonesia on risk management reveal that there is a maturity level for the application of integrated risk management in Indonesia. In 2019, the implementation of Integrated Risk Management or Enterprise Risk Management (ERM) has been carried out by most institutions in Indonesia, both government and private institutions. This can be seen from as many as $76.12 \%$ of respondents who stated that the institution where they work has implemented Integrated Risk Management or Enterprise Risk Management (ERM). The high number of institutions that have implemented Integrated Risk Management or Enterprise Risk Management shows that the application of Risk Management in Indonesia is increasingly mature from year to year. The increased maturity of risk management in Indonesia is due to the increasing number of institutions, both government and private, which implement Integrated Risk Management or Enterprise Risk Management (ERM) when compared to the previous year. See figure 2 bellow. 


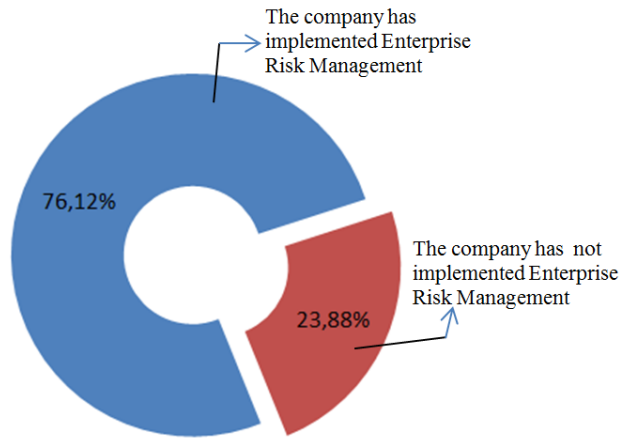

Fig. 2. ERM implementation in companies.

Firm value is the investor's perception of the company's success rate which is often associated with stock prices. A high stock price will create a high company value and increase market confidence not only in the company's current performance but also in the company's prospects in the future. Maximizing company value is very important for the company, because maximizing company value means maximizing the main objective of the company or the parent company.

In business activities, the value of the company is a reference to gain or suffer losses. This is in accordance with Brigham [3], which states that company value is the selling value of a company as an operating business. Any excess in the selling value over the liquidation value is the value of the management organization that runs the company. The development of company value in the banking and construction $\&$ building industries is shown in the figure 3 and 4 below.

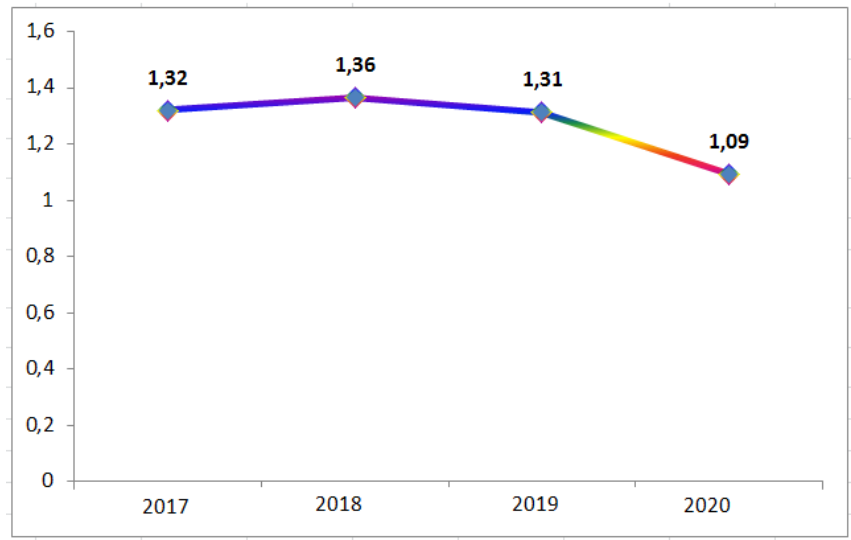

Fig. 3. Development of firm value in the banking industry.

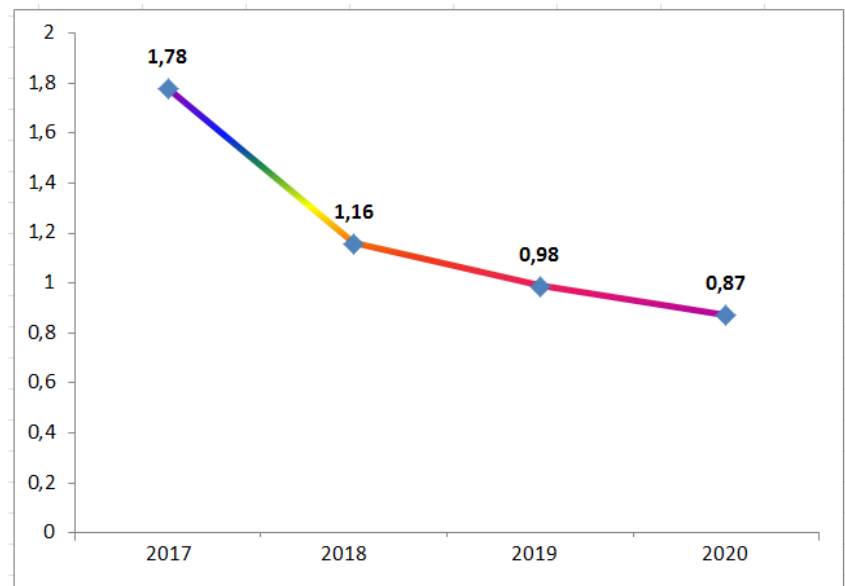

Fig. 4. Development of company value in the construction \& property industry.

Company risk management is a process related to planning, organizing, implementing, and monitoring company activities to reduce risks that will occur and have an impact on the Company's performance.

The company should implement corporate risk management as part of the company's strategy to achieve predetermined goals. The application of corporate risk management means that there must be an addition to the organizational structure of a unit that handles risk, and will require operational costs. Companies that are able to disclose risk management with effective implementation, companies can minimize risk, so that company profits can increase. The company's always good performance has an impact on the stock price on the stock market to rise, and investors will compete to compete for shares on the stock market. The stock price in the market continues to rise, the value of the company will be higher.

Economic growth can also be interpreted as a process of increasing the production capacity of an economy which is manifested in the form of an increase in national income. Indonesia's economic growth rate before the Covid-19 pandemic experienced a significant increase. This is indicated by the indication of national income and income per capita, the number of workers that is greater than unemployment, and a reduction in the level of poverty. From the development of the stock price index during 2019, there were fluctuations which tended to decrease from January to December. Seen in the figure 5 below, the stock price index in January was 6,532.97 and in December it was 6,229.52. 


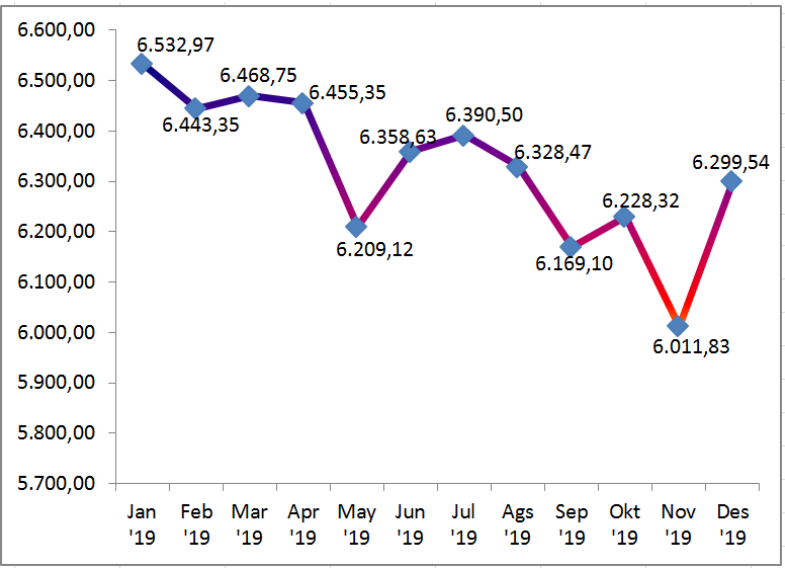

Fig. 5. The movement of the stock price index during in the year 2019 .

From the development of the stock price index in the first quarter and second quarter in the year 2020, there is a constant fluctuation from January to September. As can be seen in the figure 6 below, the stock price index in January was 5,940.05 and in December it was 5,058.48.

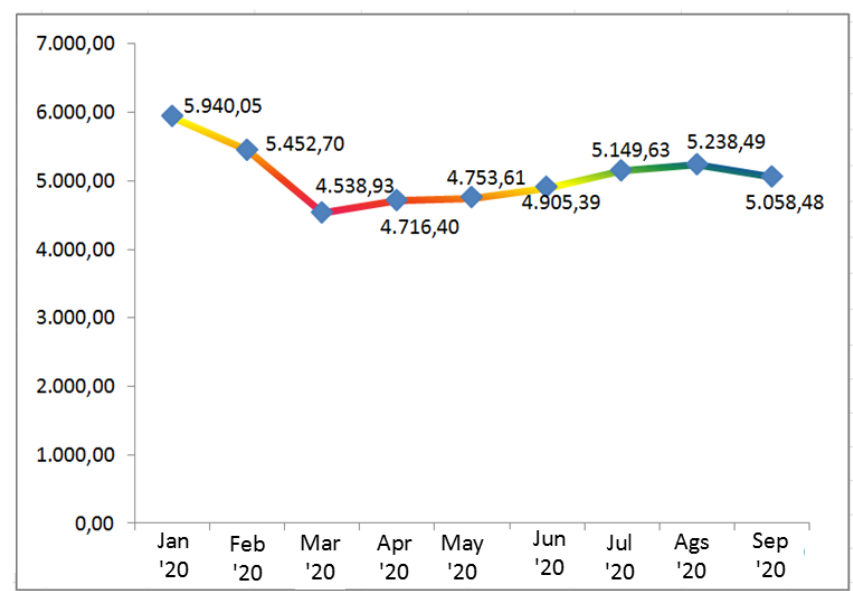

Fig. 6. The movement of the stock price index in the first quarter and second quarter in the year 2020 .

The stock price index as an indicator of company value, from the two charts before and after the pandemic, the development of the stock price index both experienced a decline. Company risk management as a strategy to improve financial performance, from this fact the application of corporate risk management does not have a significant effect on increasing firm value.

Analysis of the influence of corporate risk management and company fundamental factors on company value before the Covid-19 pandemic in Indonesia. Fundamental factors consist of firm size (FS) as measured by the logarithm of total assets, liquidity as measured by the current ratio (CR), profitability as measured by return on assets (ROA), and leverage as measured by debt ratio (DR). The results of data processing on the effect of corporate risk management (ERM) and company fundamental factors on company value before the Covid-19 pandemic, are shown in table 1 below.

TABLE I. REGRESSION COEFFICIENTS BEFORE THE COVID-19 PANDEMIC

\begin{tabular}{|l|l|l|}
\hline \multicolumn{1}{|c|}{ Variables } & \multicolumn{1}{c|}{ Beta } & \multicolumn{1}{c|}{ Sig. } \\
\hline Enterprise Risk Management (ERM) & 0,310 & 0,016 \\
Firm Size (FS) & 0,284 & 0,011 \\
Debt Ratio (DR) & $-0,089$ & 0,414 \\
Current Ratio (CR) & 0,138 & 0,122 \\
Return On Assets (ROA) & 0,155 & 0,040 \\
\hline
\end{tabular}

Based on table 1, the company's risk management variable has a regression coefficient (beta) of 0.310 , and a significance level of 0.016. Significant (Sig. <0.05) [10]. There are differences in the implementation of corporate risk management. Bank financial service companies apply corporate risk management and affect firm value. Construction \& building service companies have not fully implemented company risk management and have no effect on company value. The regression coefficient (beta) of the firm size variable is 0.284, and a significance level of 0.011. Significant (Sig. $<0.05$ ) [10]. Firm size can affect positively and significantly on firm value. A $1 \%$ increase in firm size will increase the firm's value by $28.4 \%$. The regression coefficient (beta) of the debt ratio variable was minus 0.089 , and the significance level was 0.414. Not significant (Sig.> 0.05) [10]. Debt ratio can have a negative and insignificant effect on firm value. An increase of $1 \%$ in debt ratio will not always reduce company value by $8.9 \%$, because an increase or decrease in company value does not depend on an increase or decrease in debt ratio. The regression coefficient (beta) of the current ratio variable is 0.138 , and the significance level is 0.122 . Not significant (Sig.> 0.05) [10]. The current ratio can have a positive and insignificant influence on firm value. An increase of $1 \%$ in the current ratio will not always increase the value of the company by $13.8 \%$, because an increase or decrease in company value does not depend on an increase or decrease in the current ratio. The regression coefficient (beta) of the return on assets variable is 0.155 and a significance level of 0.040. Significant (Sig. <0.05) [10]. Return on assets can have a positive and significant effect on firm value. A $1 \%$ increase in return on assets will increase the company value by $15.5 \%$. The linear regression model is $\mathrm{Y}=0.310 \mathrm{ERM}+0.284 \mathrm{FS}-0.089 \mathrm{DB}+$ $0.138 \mathrm{CR}+0.155 \mathrm{ROA}$

The results of data processing on the effect of corporate risk management (ERM) and company fundamental factors on company value after the Covid-19 pandemic, are shown in Table 2 below. 
TABLE II. REgRESSION COEFFICIENTS AFter THE COVID-19 PANDEMIC

\begin{tabular}{|l|l|l|}
\hline \multicolumn{1}{|c|}{ Variables } & \multicolumn{1}{|c|}{ Beta } & \multicolumn{1}{c|}{ Sig. } \\
\hline Enterprise Risk Management (ERM) & 0,240 & 0,471 \\
Firm Size (FS) & 0,192 & 0,529 \\
Debt Ratio (DR) & 0,302 & 0,177 \\
Current Ratio (CR) & $-0,151$ & 0,427 \\
Return On Assets (ROA) & $-0,410$ & 0,045 \\
\hline
\end{tabular}

Based on table 2, the corporate risk management variable has a regression coefficient (beta) of 0.240 , and a significance level of 0.471. Not significant (Sig.> 0.05) [10]. There is no difference in firm value between companies that implement corporate risk management and those that have not implemented corporate risk management. The regression coefficient (beta) of the firm size variable is 0.192, and the significance level is 0.529. Not significant (Sig.> 0.05) [10]. Firm size positively and insignificantly affects firm value. An increase of $1 \%$ firm size will not always increase firm value by $19.2 \%$, because an increase or decrease in firm value does not depend on an increase or decrease in firm size. The regression coefficient (beta) of the debt ratio variable was 0.302 , and the significance level was 0.177. Not significant (Sig.> 0.05) [10]. Debt ratio has no significant effect on firm value. A $1 \%$ increase in debt ratio will not always increase company value by $30.2 \%$, because an increase or decrease in company value does not depend on an increase or decrease in the debt ratio. The regression coefficient (beta) of the current ratio variable is minus 0.151 , and a significance level of 0.427 . Not significant (Sig.> 0.05) [10]. Current ratio negatively and insignificantly affects firm value. An increase of $1 \%$ of the current ratio will not always increase the value of the company by $15.1 \%$, because an increase or decrease in company value does not depend on an increase or decrease in the current ratio. The regression coefficient (beta) of the return on assets variable is 0.410, and the significance level is 0.045. Significant (Sig. $<0.05$ ) [10]. Return on assets can positively affect firm value. A $1 \%$ increase in return on assets will increase the company value by $41 \%$. The linear regression model is $\mathrm{Y}=0,240 \mathrm{ERM}+$ $0,192 \mathrm{FS}+0,302 \mathrm{DB}-0,151 \mathrm{CR}-0,410 \mathrm{ROA}$

In normal conditions, the company will be able to carry out activities according to the predetermined plan. Corporate risk management that is applied to bank service companies, can mitigate the risks that will occur. The implementation of corporate risk management in accordance with the principles and framework of risk management, provides a positive signal for investors to continue investing in the company.

The application of risk management is useful for managing risk so that it can protect and increase company value in line with improving performance and achieving company goals. The influence of external and internal factors on the company creates uncertainty in achieving company goals. Managing risk is iterative in nature and helps the company achieve its goals by setting the right strategy and making decisions based on risk management. Managing risk is part of governance and leadership, including interactions with stakeholders.
The global financial crisis during the covid-19 pandemic, made many companies start implementing risk management. It is increasingly being realized that the implementation of explicit and structured risk management brings benefits to the company's business sustainability. By taking a proactive approach to risk and effective risk management, the company will be able to achieve improvements in the following four areas: a) Strategy, the risks associated with various strategic options for company growth have been fully analyzed, so that the strategic decisions to be achieved are better. b) Tactics, consideration will be given to the selection of appropriate tactics and risks facing the company. Many alternative tactics are available so that the company will be able to face the increasingly fierce competition. c) Operations, negative events in the form of risks that can cause disruption of the company's business processes have been identified and actions are taken to reduce the likelihood of these events, minimizing costs related losses. d) Compliance, will increase due to risks associated with regulations, legal obligations and customers will be avoided.

\section{CONCLUSION}

The negative impact of the pandemic on the global economy is severe, while the prevention and control of the Covid-19 pandemic are at a crucial stage. Focusing on company performance, there will be major fluctuations in the first and second quarters of the year 2020. Managers must pay attention to the changing environment outside and adjust their business strategies in a timely manner. For investors, they must properly look at fluctuations in returns during the covid-19 pandemic, and therefore control the risks associated with financial assets invested in securities.

\section{ACKNOWLEDGMENT}

The author of this article would like to thank the State Polytechnic of Malang, Indonesia, for providing facilities and funding support for the research.

\section{REFERENCES}

[1] S. Zubair, R. Kabir, and X. Huang, "Does the financial crisis change the effect of financing on investment? Evidence from private SMEs," Journal of Business Research, vol. 110, pp. 456-463, 2020.

[2] International Organization for Standardization, (ISO) 31000:2009. Risk Management.

[3] E.F. Brigham and J.F. Houston, Fundamental of Financial Management Eleventh Edition. Thomson Higher Education 5191 Natorp Boulevard Mason, OH 45040 USA, 2007.

[4] IDX, "Indonesia Stock Exchange," [online]. Retrieved from www.idx.co.id -Indonesia Stock Exchange

[5] L. Agustina and N. Baroroh, "The Relationship Between Enterprise Risk Management (ERM) And Firm Value Mediated Through The Financial Performance,” Review of Integrative Business Economics Research, vol. 5, no. 1, pp. 128-138, 2016. 
[6] I.M. Tahir and A.R. Razali, "The Relationship Between Enterprise Risk Management (ERM) and Firm Value: Evidence From Malaysian Public Listed Companies," International Journal of Economics and Management Sciences, Management Journals, vol. 1, no. 2, pp. 32-41, 2011.

[7] N. Nasir, "Effect Of Enterprise Risk Management On Firm Value: Empirical Evidence From Non-Financial Firms In Pakistan," International Journal Of Financial Management, vol. 8, no. 4, pp. 15-28, 2018.
[8] J.W. Creswell, Qualitative Inquiry\& Research Design Choosing Among Five Approaches. Second Edition. California: Sage Publications, Inc. 2455 Teller Road Thousand Oaks, 2007.

[9] Committee of Sponsoring Organizations of the Treadway Commission (COSO), 2004.

[10] U. Sekaran, Research Methods For Business, A Skill Building Approach, Seventh Edition. United Kingdom: John Willey \& Sons, Ltd, 2003. 